\title{
JNPH
}

Volume 7 No. 1 (April 2019)

(C) The Author(s) 2019

\section{HUBUNGAN TINGKAT KECEMASAN, STATUS GIZI DAN DUKUNGAN KELUARGA TERHADAP PERILAKU WANITA MASA MENOPOUSE}

\author{
RELATIONSHIP BETWEEN ANXIETY LEVELS, NUTRITIONAL STATUS AND \\ FAMILY SUPPORT AGAINST THE BEHAVIOR OF WOMEN DURING MENOPOUSE
}

\author{
LIA PUSPITA ${ }^{1}$, RENI MARLINA ${ }^{2}$ \\ PROGRAM STUDI KEBIDANAN PROGRAM SARJANA TERAPAN \\ SEKOLAH TINGGI ILMU KESEHATAN INDONESIA MAJU \\ JLN.HARAPAN NOMOR 50, LENTENG AGUNG-JAKARTA SELATAN \\ 12610 TELP: (021)78894045 \\ Email: liapuspita898@gmail.com, marlinareni62@gmail.com
}

\begin{abstract}
ABSTRAK
Berdasarkan data statistik dari Departemen Kesehatan pada tahun 2000 jumlah penduduk wanita berusia 50 tahun keatas telah mencapai 15,5 juta orang. Tujuan penelitian ini untuk mengetahui hubungan antara tingkat kecemasan, status gizi dan dukungan keluarga terhadap perilaku wanita masa menopouse di wilayah kerja puskesmas sawah lebar kota bengkulu tahun 2017. Jenis penelitian ini adalah metode deskritif analitik dengan pendekatan cross sectional dan yang menjadi populasi yaitu wanita menopouse di puskesmas sawah lebar kota bengkulu tahun 2017, sedangkan sampel sebanyak 59 orang dan pengambilan sampel dengan menggunakan metode Accidental Sampling. Dan analisa data mencakup analisa univariat dan analisa bivariat dengan uji chi-square. Hasil dari 59 responden didapatkan bahwa tingkat kecemasan ringan berjumlah 29 responden (49,2\%) dan tingkat kecemasan berat berjumlah 30 responden $(50,8 \%)$ sedangkan dari status gizi baik berjumlah 24 responden $(40,7 \%)$ dan status gizi kurang berjumlah 35 responden $(59,3 \%)$ dan katagori dukungan keluarga baik berjumlah 26 responden $(44,1 \%)$ dan dukungan keluarga kurang berjumlah 33 responden $(55,9 \%)$. Kesimpulan penelitian ini adalah ada hubungan yang bermakna antara tingkat kecemasan dengan perilaku wanita menopouse $(\mathrm{P}$-value $=0,001)<0,05$ OR 7,600 , ada hubungan yang bermakna antara status gizi terhadap perilakui wanita menopouse $(\mathrm{P}-$ value $=0,004<\mathrm{OR} 5,778$ dan ada hubungan yang bermakna antara dukungan keluarga terhadap perilaku wanita menopouse $(\mathrm{P}-$ value $=0,001)<0,05$ OR 8, 357. Diharapkan kepada wanita menopouse untuk mengantisipasi sejak dini komplikasi yang mungkin terjadi saat menopouse dengan cara memeriksakan diri ketenaga kesehatan sehingga angka kesakitan akibat perilaku wanita masa menopouse dapat menurun.
\end{abstract}

Kata kunci : Dukungan Keluarga, Status Gizi, Tingkat Kecemasan, Wanita menopouse

\begin{abstract}
ABSTACT
Based on statistical data from the Ministry of Health in 2000 the number of female population aged 50 years and over has reached 15.5 million people. The purpose of this study to determine the relationship between the level of anxiety, nutritional status and family support to the
\end{abstract}


behavior of menopause women in the working area of public health centers wide field of bengkulu city in 2017. This research type is descriptive analytic method with cross sectional approach and the population that is menopause women in puskesmas wide rice field of bengkulu city in 2017, while sample as many as 59 people and sampling using Accidental Sampling method. Data analysis included univariate analysis and bivariate analysis with chisquare test. Results from 59 respondents found that the level of mild anxiety was 29 respondents (49.2\%) and the level of severe anxiety amounted to 30 respondents $(50.8 \%)$ while from the status good nutrition was 24 respondents $(40,7 \%)$ and nutrient status was less 35 respondents $(59,3 \%)$ and good family support category was 26 respondents $(44,1 \%)$ and family support was less 33 respondents $(55,9 \%)$. The conclusion of this study is that there is a significant relationship between anxiety level and the behavior of female menopause (P-value $=$ $0.001)<0.05$ OR 7,600 , there is a significant correlation between nutritional status to behavior of female menopause $(\mathrm{P}$ - value $=0,004<\mathrm{OR} 5,778$ and there is a significant relationship between family support for the behavior of female menopause $(\mathrm{P}$-value $=0.001)<0.05$ OR 8 , 357. It is expected to menopause women to anticipate early complications that may occur at the menopause by checking self-health health so that the number of morbidity due to the behavior of menopause women may decline.

\section{Keywords : female menopouse, anxiety level, nutritional status, family support}

\section{PENDAHULUAN}

Menopouse adalah fase alami setiap wanita yang ditandai berakhirnya masa subur. Menopause terjadi karena ovarium tidak memproduksi hormon estrogen. Wanita yang mengalami menopause secara Prilaku dan psikologi sering merasa gelisah. Hal ini disebabkan menurunnya fungsi seksual pada wanita yaitu perubahan rasa nyaman saat melakukan hubungan seksual dengan pasangannya.

Dari data WHO (World Health Organization), sindrom menopouse banyak dialami wanita sangat hampir diseluruh dunia, seperti $70-80 \%$ wanita Eropa. 60\% di Amerika, 57\% di Malaysia, 18\% di China, dan $10 \%$ di Jepang. Berdasarkan data statistik dari Departemen Kesehatan pada tahun 2009 penduduk Indonesia telah berjumlah 201,4 juta dan 100,9 juta diantaranya adalah wanita, termasuk 14,3 juta orang wanita berusia 50 tahun ke atas. Pada tahun 2000 jumlah penduduk wanita berusia 50 tahun ke atas telah mencapai 15,5 juta orang dan diperkirakan pada tahun 2020 jumlah perempuan hidup dalam usia menopouse tersebut terus bertambah jumlahnya menjadi 30,3 juta jiwa.
Data survei dasar dari negara berkembang, memperlihatkan penduduk usia 45 tahun keatas makin meningkat dari tahun 1980 sampai tahun 2000 dari 206 juta menjadi 257 juta, angka ini diperkirakan akan terus naik. Menurut WHO pada tahun 2030 jumlah perempuan umur 50 tahun atau lebih diperkirakan mencapai 1,2 milyar.

Jumlah proporsi penduduk perempuan yang berusia di atas 50 tahun yang akan diperkirakan memasuki usia menopause (berhenti siklus haid), dari tahun ke tahun mengalami peningkatan yang sangat signifikan Diperkirakan pada tahun 2030, jumlah perempuan di dunia yang memasuki masa menopause diperkirakan mencapai 1,2 miliar orang. Menurut proyeksi penduduk Indonesia tahun 1995-2005 oleh Badan Pusat Statistik, jumlah penduduk perempuan berusia di atas 50 tahun adalah 15,9 juta orang, dan tahun 2025 diperkirakan akan ada 60 juta perempuan menopause.

Berdasarkan profil data puskesmas sawah lebar kota bengkulu, dari data laporan menopouse bulan desember 2016 jumlah wanita menopouse sebanyak 143 orang, sedangkan jumlah pria menopouse sebanyak 109 orang. Jumlah keseluruhan menopouse di wilayah kerja puskesmas sawah lebar kota 
bengkulu sebanyak 252 orang.

Salah satu masalah kesejahteraan masyarakat dapat di ukur dari angka harapan hidup. Angka harapan hidup di negara maju sudah semakin tinggi, hal ini mengakibatkan berkembangnya jumlah penduduk lansia. Proses penuaan penduduk berdampak pada berbagai aspek kehidupan baik sosial, ekonomi dan terutama kesehatan, karena dengan semakin bertambahnya usia, fungsi organ akan semakin menurun baik karena faktor alamiah maupun karena penyakit. Dengan demikian, peningkatan jumlah penduduk lanjut usia menjadi salah satu indikator keberhasilan pembangunan sekaligus sebagai tantangan dalam pembangunan, mengingat tidak sedikit masalah yang timbul akibat penuaan.

Seiring meningkatnya usia, sangat banyak terjadi proses perkembangan dan pertumbuhan pada manusia. Perkembangan dan pertumbuhan akan berhenti pada suatu tahapan, sehingga selanjutnya banyak perubahan yang terjadi pada fungsi tubuh. Perubahan tersebut biasanya akan terjadi pada proses menua, karena pada proses ini banyak terjadi perubahan perilaku maupun psikologis.

Kecemasan pada setiap orang berbedabeda, ada yang ringan, sedang dan juga ada yang berat, sehingga membutuhkan upaya penanganan untuk mengatasi kecemasan yang terjadi. Sebenarnya berbagai upaya penanganan yang ada hanya dapat membuat wanita yang menjalaninya merasa baik. Tetapi hal ini juga sangat dipengaruhi dan ditentukan oleh kondisi psikis. Faktor lain yang menggangu kondisi gizi menopouse secara tidak langsung ialah prilaku dan psikis yang sensitif.

Status Gizi yaitu suatu proses dimana penggunaan makanan yang dikonsumsi secara normal oleh suatu organisme melalui proses digestin, absorbs, transpormasi, penyimpanan, metabolism dan pengeluaran zat-zat yang tidak digunakan untuk mempertahankan kehidupan, pertumbuhan dan fungsi normal dari organ-organ, serta menghasilkan energy. Gizi menopouse menbutuhkan sari makanan mengandung zat gizi yang dibutuhkan untuk menunjang gizi menopouse. Pada menopouse, fungsi indra penciuman dan perasa menurun sehingga menyebabkan makanan dengan rasa asin yang cukup pun sering terasa hambar sehingga sering terjadi hipertensi. Penuaan yang terjadi pun menyebabkan keterbatasan lansia untuk mencerna makanan.

Dukungan keluarga sangat menjadikan wanita yang menghadapi masa menopause menjadi sangat berharga dan menambah ketentraman hidup. Dukungan keluarga yaitu suatu dukungan yang diterima seseorang dari orang yang berada dalam lingkungan keluarga seperti suami, anak dan orang tua sehingga merasa diperhatikan, dihargai dan dicintai. Dukungan keluarga meliputi dukungan emosional, penghargaan, instrumental dan informatif. Manfaat dukungan keluarga yaitu menjadikan seorang wanita untuk menghadapi masa menopause lebih mudah.

Oleh karenan itu, ibu yang mendapat dukungan keluarga akan merasa mendapat kepedulian, perlindungan serta rasa aman dari orang - orang disekitarnya. Memasuki usia tengah baya 40 tahun, wanita mengalami menopause. Terjadinya menopause membawa perubahan-perubahan dalam kehidupannya. Perubahan tersebut meliputi perubahan fisik dan perilaku. Mulai dari perubahan berat badan, perubahan bentuk tubuh, kulit keriput, suasana hati yang berubah-ubah.

Berdasarkan uraian di atas maka peneliti bermaksud untuk mengetahui hubungan tingkat kecemasan, status gizi dan dukungan keluarga terhadap perilaku wanita masa menopouse diwilayah kerja puskesmas sawah lebar kota bengkulu tahun 2017.

\section{METODE PENELITIAN}

Pada penelitian ini menggunakan metode analitik deskriptif dengan pendekatan cross sectional. Instrumen yang digunakan dalam penelitian ini adalah kuesioner, meliputi pernyataan terstruktur dan berkaitan dengan variabel yang akan diteliti.

Penelitian ini dilakukan di Wilayah Puskesmas Sawah Lebar Kota Bengkulu. 
Populasi dalam penelitian ini adalah semua wanita menopouse berumur 45-60 pada tahun 2017 yang berjumlah 143 Orang. Teknik pengambilan sampel menggunakan teknik metode accidental sampling dengan jumlah sampel 59 Orang.

Teknik pengambilan samel dalam penelitian ini menggunakan teknik Accidental sampling yaitu penentuan sampel dengan mengumpulkan data langsung dari setiap sampel yang dijumpai sampai jumlah yang diharapkan terpenuhi.

Langkah-langkah yang perlu ditempuh dalam mengambil sampel yaitu menentukan tujuan penelitian, menentukan populasi penelitian, menentukan jenis data yang diperlukan, menentukan tekhnik sampling, menentukan besarnya sampel, menentukan unit sampel yang diperlukan dan memilih sampel.

Syarat sampel Agar karakteristik sampel tersebut tidak menyimpang dari populasinya, perlu juga ditentukan kriteria inklusi maupun eksklusi. Kriteria inklusi adalah karakteristik subjek penelitian dari suatu populasi merupakan target yang akan diteliti yang dapat diambil sebagai sampel. Kriteria inklusi pada penelitian ini yaitu Wanita yang menopouse Diwilayah Kerja Puskesmas Sawah Lebar Kota Bengkulu Tahun 2017 dan yang bersedia menjadi responden.

Kriteria non inklusi merupakan kriteria yang tidak termasuk dalam penelitian. Sampel dalam penelitian ini yang memiliki kriteria non inklusi ibu yang masih menggalami menstruasi dan selain wanita yang berumur 45-59 tahun di wilayah kerja puskesmas sawah lebar kota Bengkulu tahun 2017.

Kriterian eksklusi adalah keadaan yang menyebabkan subjek penelitian yang memenuhi kriteria inklusi tetapi tidak dapat diikut sertakan dalam penelitian yaitu wanita menopouse yang tidak datang ke puskesmas sawah lebar kota bengkulu tahun 2017.

Sebelum instrumen atau alat ukur digunakan untuk penelitian maka dilakukan uji coba kuesioner terlebih dahulu yaitu dilakukan uji validitas dan reliabilitas. Analisa data dalam penelitian ini menggunakan bantuan komputerisasi SPSS 17.

Validitas adalah suatu ukuran yang dapat menunjukan tingkat kevalidan suatu instrumen. Untuk mengetahui validitas item dalam penelitian ini jika $r$ hitung $>r$ tabel maka dapat dikatakan butir soal tersebut valid. Untuk mengetahui validitas kuesioner dilakukan dengan membandingkan nilai $\mathrm{r}$ hitung (dalam output SPSS dinotasikan sebagai corrected item total) dengan $\mathrm{r}$ tebel menggunakan $\mathrm{df}=\mathrm{n}-2$ ( $\mathrm{n}=$ jumlah responden), dengan tingkat keprcayaan yang digunakan 95\%.Reliabilitas adalah indeks yang menunjukan sejauh mana suatu alat pengukur dapat dipercaya atau dapat diandalkan.

Dalam penelitian ini menggunakan uji chi square karena data yang digunakan dalam bentuk data kategorik. Dalam penelitian kesehatan sering kali peneliti perlu melakukan analisis hubungan variabel kategorik dengan variabel kategorik. Analisis ini bertujuan untuk menguji perbedaan proporsi dua atau lebih kelompok sampel, dalam hal ini uji yang cocok digunakan yaitu uji chi square.

Analisa univariat yaitu analisa yang dilakukan terhadap tiap variabel dari hasil penelitian yang dinyatakan dengan bentuk distribusi frekuensi. Hasil analisa tersebut disajikan dalam bentuk tabel yang bertujuan untuk melihat distribusi frekuensi dari semua variabel yang diteliti.

Dalam penelitian ini menggunakan uji chi square karena data yang digunakan dalam bentuk data kategorik. Dalam penelitian kesehatan sering kali peneliti perlu melakukan analisis hubungan variabel kategorik dengan variabel kategorik. Analisis ini bertujuan untuk menguji perbedaan proporsi dua atau lebih kelompok sampel, dalam hal ini uji yang cocok digunakan yaitu uji chi square.

Analisa bivariat digunakan apabila ingin melihat hubungan antara variabel independen dan variabel dependen yang bertujuan untuk mengetahui apakah ada hubungan antara variabel bebas (tingkat kecemasan, status gizi dan dukungan keluarga) dan variebel terikat 
(perilaku wanita menopouse). Melalui uji chi square akan diperoleh nilai $\mathrm{P}$ value, dimana dalam penelitian ini digunakan tingkat kemaknaan sebesar 0,05. Penelitian antara dua variabel dikatakan bermakna jika mempunyai nilai $\mathrm{P}<0,05$ yang berarti $\mathrm{HO}$ ditolak dan Ha diterima. Dan dikatakan tidak bermakna jika mempunyai nilai $\mathrm{P}>0,05$ yang berarti Ho diterima dan Ha ditolak.

Kriteria yang digunakan dalam uji chi square yaitu dengan tingkat kemaknaan $(\alpha)=$ 0,05 . Jika $\mathrm{P}$ Value $<0,05$ maka secara signifikan ada hubungan antara variabel dependen dengan variabel independen dan apabila $\mathrm{P}$ Value $>0,05$ berarti tidak ada hubungan antara variabel dependen dengan variabel independen. Sedangkan untuk mengetahui keeratan hubungan atau kekuatan hubungan digunakan odds ratio (OR).

Interpretasi disampaikan secara narasi sehingga memudahkan pemahaman terhadap hasil penelitian, interpretasi digunakan untuk melihat Hubungan Tingkat Kecemasan, Status Gizi Dan Dukungan Keluarga Terhadap Perilaku Wanita Masa Menopuse Di Wilayah Puskesmas Sawah Lebar Kota Bengkulu tahun 2017 pada bulan 02-27 maret tahun 2017.

\section{HASIL}

\section{Analisis Univariat}

Analisis univariat dilakukan dengan tujuan untuk melihat gambaran distribusi variabel-variabel yang diteliti. Variabelvariabel penelitian ini meliputi variabel independen (tingkat kecemasan, status gizi, dukungan keluarga) dan variabel dependen (perilaku wanita masa menopouse) Di Wilayah Puskesmas Sawah Lebar Kota Bengkulu tahun 2017 pada bulan 02-27 maret tahun 2017

Tabel 1. Distribusi frekuensi perilaku wanita menopouse, tingkat kecemasan, status gizi dan dukungan keluarga

\begin{tabular}{|c|c|c|}
\hline Variabel & $\begin{array}{c}\text { Frekuensi } \\
\text { (f) }\end{array}$ & $\begin{array}{c}\text { Presentase } \\
(\%)\end{array}$ \\
\hline \multicolumn{3}{|c|}{ Perilaku Wanita Menopouse } \\
\hline Tidak mengalami & 25 & 42,4 \\
\hline mengalami & 34 & 57,6 \\
\hline \multicolumn{3}{|l|}{ Tingkat Kecemasan } \\
\hline Ringan & 29 & 49,2 \\
\hline Berat & 30 & 50,8 \\
\hline \multicolumn{3}{|c|}{ Status Gizi } \\
\hline Baik & 24 & 40,7 \\
\hline Kurang & 35 & 59,3 \\
\hline \multicolumn{3}{|c|}{ Dukungan Keluarga } \\
\hline Baik & 26 & 44,1 \\
\hline Kurang & 33 & 55,9 \\
\hline
\end{tabular}

Sumber : Hasil Olahan Data Tahun 2017

\section{Analisis Univariat}

Berdasarkan tabel 1 diatas variabel perilaku wanita menopouse diketahui mayoritas reponden mengatakan mengalami perubahan perilaku yaitu sebanyak 34 orang atau $67,6 \%$, kemudian pada variabel tingkat kecemasan diketahui bahwa responden yang yang mengalami kecemasan berat yaitu sebanyak 30 orang atau $50,8 \%$, selanjutnya pada variebel status gizi diketahui mayoritas responden mengatakan status gizi kurang yaitu sebanyak 35 orang atau $59,3 \%$ dan pada variabel dukungan keluarga diketahui bahwa mayoritas responden mengatakan dukungan keluarga masih kurang mendukung yaitu sebanyak 33 orang atau 55,9\%.

Tabel 2. Hubungan Tingkat Kecemasan, Status Gizi Dan Dukungan Keluarga Terhadap Status Gizi Terhadap Perilaku Wanita Masa Menopouse 


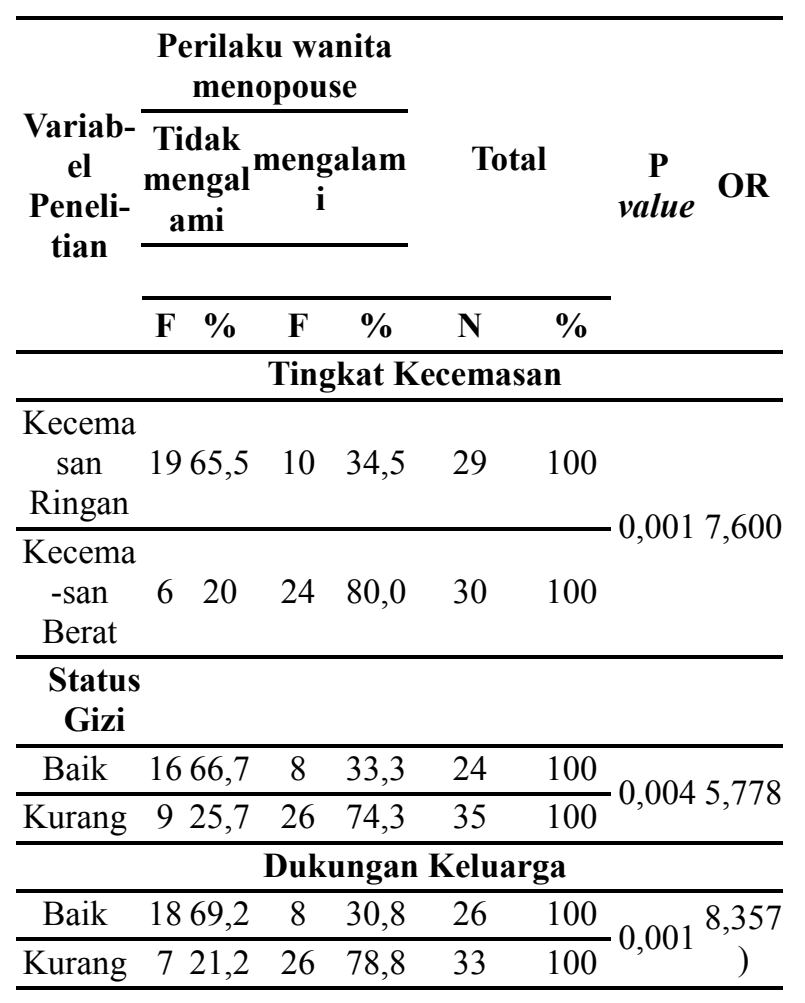

Sumber : Hasil Olahan Data Tahun 2017

\section{Analisis Bivariat}

Berdasarkan tabel 2 diatas diperoleh hasil bivariat yang bertujuan untuk mengetahui hubungan antara variabel independen (tingkat kecemasan, status gizi dan dukungan keluaraga) dan variabel dependen (perilaku wanita menopouse) Di Wilayah Kerja Puskesmas Sawah Lebar Kota Bengkulu Tahun 2017. Analisa bivariat digunakan apabila ingin melihat hubungan antara variabel independen dan variabel dependen.

Hasil analisis hubungan antara tingkat kecemasan terhadap perilaku wanita masa menopouse diperoleh bahwa ada sebanyak 19 ( 65,5\%) dari 29 wanita tingkat kecemasan ringan tidak mengalami perubahan perilaku wanita menopouse, sedangkan diantara wanita yang tingkat kecemasan berat ada 6 ( $20 \%$ ) dari 30 yang tidak mengalami perubahan perilaku wanita menopouse. Hasil uji statistik diperoleh nilai $\mathrm{p}=0,001$ maka dapat disimpulkan ada perbedaan perilaku wanita menopouse antara tingkat kecemasan ringan dan tingkat kecemasan berat ( ada hubungan yang signifikan antara tingkat kecemasan ringan dan tingkat kecemasan berat). Dari hasil analisis diperoleh nilai OR 7,600, artinya tingkat kecemasan ringan mempunyai peluang 7,600 ( 7,6 ) kali tidak mengalami perubahan perilaku wanita masa menopouse dibanding tingkat kecemasan berat.

Hasil analisis hubungan antara status gizi terhadap perilaku wanita masa menopouse diperoleh bahwa ada sebanyak 16 ( $66,7 \%$ ) dari 24 wanita status gizi baik tidak mengalami perubahan perilaku wanita menopouse, sedangkan diantara wanita yang status gizi kurang ada $9(25,7 \%)$ dari 35 yang tidak mengalami perubahan perilaku wanita menopouse. Hasil uji statistik diperoleh nilai $\mathrm{p}=0,004$ maka dapat disimpulkan ada perbedaan perilaku wanita menopouse antara status gizi baik dan status gizi kurang ( ada hubungan yang signifikan antara status gizi baik dan status gizi kurang). Dari hasil analisis diperoleh nilai OR 5,778, artinya status gizi baik mempunyai peluang 5,778 ( 7,8 ) kali tidak mengalami perubahan perilaku wanita masa menopouse dibanding status gizi kurang.

Hasil analisis hubungan antara dukungan keluarga terhadap perilaku wanita masa menopouse diperoleh bahwa ada sebanyak 18 $(69,2 \%)$ dari 26 wanita dukungan keluarga baik tidak mengalami perubahan perilaku wanita menopouse, sedangkan diantara wanita yang dukungan keluarga kurang ada 7 $(21,2 \%)$ dari 33 yang tidak mengalami perubahan perilaku wanita menopouse. Hasil uji statistik diperoleh nilai $\mathrm{p}=0,001$ maka dapat disimpulkan ada perbedaan perilaku wanita menopouse antara dukungan keluarga baik dan dukungan keluarga kurang ( ada hubungan yang signifikan antara dukungan keluarga baik dan dukungan keluarga kurang). Dari hasil analisis diperoleh nilai OR 8,357, artinya dukungan keluarga baik mempunyai peluang 8,357 ( 8,4 ) kali tidak mengalami perubahan perilaku wanita masa menopouse dibanding dukunga keluarga kurang atau Dapat dikatakan, perilaku merupakan respon individu terhadap suatu 
stimulus atau suatu tindakan yang dapat diamati dan mempunyai frekuensi spesifik, durasi serta tujuan baik yang disadari maupun tidak.

\section{PEMBAHASAN}

\section{Analisis Univariat}

\section{Perilaku Wanita Menopouse}

Berdasarkan hasil univariat dalam penelitian terhadap 59 responden, dapat diketahui bahwa yang mengalami perubahan perilaku masa menopouse sebanyak 34 orang $(57,6 \%)$ sedangkan yang tidak mengalami perubahan perilaku masa menopouse sebanyak 25 orang $(42,4 \%)$.

Menurut hasil penelitian Hesty Destia Indrias (2015) terdapat 66 responden banyak mengalami perubahan perilaku pada kategori kuat 29 orang $(43,9 \%)$ sedangka paling sedikit perubahan perilaku pada kategori cukup 13 orang $(19,7 \%)$.

Dapat dikatakan, perilaku merupakan respon individu terhadap suatu stimulus atau suatu tindakan yang dapat diamati dan mempunyai frekuensi spesifik, durasi serta tujuan baik yang disadari maupun tidak. Kumpulan dari faktor-faktor yang saling berinteraksi juga disebut perilaku. Perilaku dilihat dari aspek biologis dapat diartikan sebagai kegiatan organisme atau makhluk hidup yang bersangkutan.

Berdasarkan pendapat peneliti dari hasil penelitian ini dapat diketahui bahwa perilaku wanita masa menopouse dapat dipengaruhi oleh tingkat kecemasan, status gizi dan dukungan keluarga oleh sebab itu harus dicegah dan ditanggulangi sejak dini agar tidak terjadi masalah perilaku wanita masa menpouse, hal ini bisa di cegah dengan memberikan penyuluhan kepada wanita yang ber umur 45-60 tahun agar secara rutin memeriksakan dirinya dan selalu menjaga status gizi dan kebiasaan hidup sehat, kesehatan selalu terjaga serta bisa terhindar dari masalah perubahan perilaku wanita masa menopouse.

\section{Tingkat Kecemasan}

hasil penelitian terhadap 59 responden, dapat diketahui bahwa yang mengalami kecemasan berat sebanyak 30 orang $(50,8 \%)$ sedangkan yang tidak mengalami kecemasan ringan sebanyak 29 orang (49,2\% ).

Berdasarkan hasil penelitian tri mistimah (2011) terhadap 62 responden sebagian besar wanita menopause mengalami cemas yaitu sebesar 57 orang $(67,9 \%)$. Sedangkan sisanya mengalami tidak cemas yaitu 27 orang $(32,1 \%)$. Sedangkan penelitian yang dilakukan peneliti trisnawati (2014) Tingkat kecemasan wanita menopause di Desa Dawuhan Kecamatan Purwoasri Kabupaten Kediri sebagian besar mengalami cemas yaitu 57 orang $(67,9 \%)$. Sedangkan sisanya tidak cemas yaitu 27 orang $(32,1 \%)$.

Kecemasan adalah situasi yang tegang ketika seseorang menghadapi masalah atau tantangan dan belum mempunyai jalan keluar sehingga menganggu aktivitas yang akan dilakukannya. Individu yang mengalami kecemasan menujukkan gejala otot-otot tubuh mudah menjadi tegang, seperti dada terasa sesak, tengkuk keram dan tekanan darah meningkat, keadaan ini jika dibiarkan akan berdampak pada fisik dan psikologis perilaku individu.

Berdasarkan pendapat peneliti dari asil penelitian ini dapat diketahui bahwa masalah psikologi wanita masa menopouse dapat di pengaruhi oleh tingkat kecemasan. Hal ini mengkin karena semakin berat tingkat kecemasan maka semakin cenderung menjadi mudah stress dan tubuhnya mengalami ketegangan sehingga menyebakan perubahan fisiologis sehingga akan mempengaruhi psikologi ibu masa menopouse. Gangguan masa menopause pada wanita menopause terjadi akibat penurunan kadar estrogen dan progesteron yang dapat berpengaruh secara fisik maupun psikis sehingga dapat mempengaruhi berbagai aktivitas kehidupan wanita menopause tersebut. 


\section{Status Gizi}

Diatas dari hasil penelitian terhadap 59 responden, dapat diketahui bahwa yang status gizi kurang sebanyak 35orang (59,3\%) sedangkan yang tidak mengalami status gizi baik sebanyak 24 orang ( $40,7 \%$ ).

Berdasarkan hasil penelitian dewi arliana ( 2017 ) Berdasarkan hasil penelitian pada 36 responden diperoleh hasil sebagian besar responden pada tingkat status gizi kurang sebanyak $25(69,4 \%)$ sedangkan yang baik hanya sebanyak $11(30,6 \%)$ responden.

Berdasarkan hasil penelitian, Status gizi adalah keadaan gizi seseorang yang menggambarkan apa yang dikonsumsinya dalam waktu yang cukup lama, dimana keadaan gizi ini merupakan akibat dari keseimbangan antara konsumsi dengan penyerapan zat gizi dan penggunaan zat-zat tersebut atau keadaan fisiologik akibat tersedianya zat gizi dalam seluler tubuh Sebagai salah satu tanda-tanda terjadinya masa menopause adalah keluhan terjadinya perubahan fisik dan psikologi pada seseorang wanita.

Berdasarkan pendapat peneliti dari hasil penelitian ini dapat diketahui bahwa perilaku wanita masa menopouse dapat dipengaruhi oleh status gizi, nutrisi yang buruk pada menopouse dapat mengakibatkan perubahan perilaku yang lebih menjadi sensitif, kebutuhan kalori saat menopouse 1700 pada wanita, bergantung kepada keadaan kurus, atau gemuk, Karbohidrat $60 \%$ dari jumlah kalori yang dibutuhkan, Lemak tidak dianjurkan, karena menyebabkan hambatan pencernaan, Protein untk mengganti sel yang rusak 20-25\% dari total yang dibutuhkan, Kebutuhan vitamin dan mineral sama dengan usia muda, Air 6-8 gelas per hari. Angka ini merupakan nilai normal dari kebutuhan gizi wanita masa menopouse, jika kebutuhan status gizi kurang maka akan mengakibatkan psikologis perilaku wanita masa menopouse menjadi sensitif dan bahkan strees atu depresi juga.

\section{Dukungan Keluarga}

dari hasil penelitian terhadap 59 responden, dapat diketahui bahwa yang dukungan keluarga yang kurang sebanyak 33 orang ( $5,95 \%$ ) sedangkan yang dukungan keluarga yang baik sebanyak 26 orang (44,1\%).

Berdasarkan hasil penelitian Azka Milatina ( 2015 ) korelasi antara dukungan keluarga (sosial) dengan perubahan perilaku menopouse sebesar 0,658 yang menunjukan bahwa adanya hubungan positiff yang kuat antara dukungan sosial dengan perubahan perilaku pada wanita menopouse di Rs Harapan Bunda. Semakin tinggi dukungan keluarga (sosial) maka semakin tinggi perubahan perilaku wanita menopouse di RS Harapan Bunda, begitu pula sebaliknya. Sumbangan efektif variabel dukungan keluarga ( sosial ) sebesar 43,3\% yang artinya variabel dukungan keluarga (sosial) memiliki hubungan sebesar $43,4 \%$ pada perubahan perilaku menopouse.

Dukungan instrumental berupa bantuan langsung, memberi pinjaman dan membantu pekerjaan pada wanita menopouse dapat memperlihatkan adanya rasa kasih sayang yang diberikan oleh orang-orang terdekat sehingga akan menimbulkan dorongan kuat untuk mengatasi masalahny. Dukungan yang tepat dan dapat dipercaya dari oran-orang terdekat dapat mempengaruhi seorang dalam menghadapi masalahnya dengan penilaian yang positif, orang terdekat memiliki peran untuk memberikan pendapat dan umpan balik mengenai masalah menopouse yang sedang dihadapinya.

Berdasarkan pendapat peneliti dari asil penelitian ini dapat diketahui bahwa masalah perilaku wanita masa menopouse dapat di pengaruhi oleh dukungan keluarga. Hal ini mengkin karena semakin kurang dukungan keluarga yang diberikan maka semakin cenderung menjadi mudah stress dan tubuhnya mengalami ketegangan sehingga menyebakan perubahan fisiologis sehingga akan mempengaruhi psikologi ibu masa menopouse. Dan karena semakin baik 
dukungan keluarga yang diberikan maka semakin memperlihatkan adanya rasa kasih sayang yang diberikan oleh orang-orang terdekat sehingga akan menimbulkan dorongan kuat untuk mengatasi masalahnya. Jika cenderung menjadi Gangguan masa menopause pada wanita menopause terjadi akibat penurunan kadar estrogen dan progesteron yang dapat berpengaruh secara fisik maupun psikis sehingga dapat mempengaruhi berbagai aktivitas kehidupan wanita menopause tersebut.

\section{Analisis Bivariat}

\section{Hubungan Tingkat Kecemasan Terhadap Perilaku Wanita Menopouse}

Berdasarkan hasil penelitian analisa bivariat dengan 59 responden, hubungan tingkat kecemasan terhadap perilaku wanita masa menopouse dapat diketahui bahwa Hasil uji statistik diperoleh nilai $\mathrm{P}=0,001$ dalam hal ini nilai $\alpha<0,05$ yaitu Ho ditolak dan pernyataan $\mathrm{Ha}$ diterima maka dapat disimpulkan bahwa ada hubungan tingkat kecemasan dengan perilaku wanita masa menopouse. Dari hasil analisis diperoleh nilai OR 7,600, artinya tingkat kecemasan ringan mempunyai peluang 7,600 ( 7,6 ) kali tidak mengalami perubahan perilaku wanita masa menopouse dibanding tingkat kecemasan berat.

Hasil penelitian Yulia Trisnawati Dalam menganalisa data hubungan perilaku masa menopause dengan tingkat kecemasan pada ibu menopause di Desa Dawuhan, Kecamatan Purwoasri Kabupaten Kediri yaitu menggunakan analisa data Chi - square dengan taraf signifikan $5 \%$ atau $\alpha \leq 5 \%(0,05)$ dengan penghitungan manual. Sehingga didapatkan tabel 4 x 2 dan uji analisa menggunakan Chi Square metode penghitungan manual $\mathrm{X} 2$ hitung $>\mathrm{X} 2$ tabel yaitu13,75 $>$ 7,815 sehingga $\mathrm{H} 1$ terbukti yang artinya ada hubungan perubahan perilaku masa menopause dengan tingkat kecemasan pada ibu menopause di Desa Dawuhan, Kecamatan Purwoasri Kabupaten Kediri.
Dari hasil penelitian di atas, peneliti mengungkapkan bahwa tingkat kecemasan merupakan salah satu masalah yang sangat penting karena kehadirannya dapat menganggu perilaku dalam kehidupan sosial sehari-hari wanita. Akan tetapi masalah kecemasan ini harus segera diatasi agar setiap wanita yang akan memasuki masa menopause tidak mengalami kecemasan, tidak menjadi mengaktifkan saraf otonom dimana detak jantung menjadi bertambah, tekanan darah naik, frekuensi nafas bertambah dan secara umum mengurangi tingkat energi pada klien, sehingga jika, akhirnya menjadi depresi.

\section{Hubungan Status Gizi Terhadap Perilaku Wanita Menopouse}

Hasil uji statistik diperoleh nilai $\mathrm{P}=$ 0,004 dalam hal ini nilai $\alpha<0,05$ yaitu Ho ditolak dan pernyataan $\mathrm{Ha}$ diterima maka dapat disimpulkan bahwa ada hubungan status gizi dengan perilaku wanita masa menopouse. Dari hasil analisis diperoleh nilai OR 5,778, artinya status gizi baik mempunyai peluang 5,778 ( 7,8) kali tidak mengalami perubahan perilaku wanita masa menopouse dibanding status gizi kurang.

Hasil penelitian Dewi Elliana menggunakan uji Chi Square didapatkan 11,062 nilai $\mathrm{p}$ value sebesar $=0.001$ ( $\mathrm{p}$ value $<0.05$. Karena nilai $p$ value lebih kecil dari 0.05 dengan demikian Ha diterima, yang berarti ada hubungan tingkat status gizi dengan perubahan perilaku dan fisik pada masa menopause di Kelurahan Bendan Duwur Kecamatan Gajahmungkur Kota Semarang.

Menurut peneliti bahwa Hal ini menggambarkan bahwa dengan status gizi yang kurang akan dapat meningkatnya terjadinya perubahan psikologi dan perilaku pada wanita masa menopause, karena dengan keadaan status gizi yang kurang asuhan gizi yang dibutuhkan oleh tubuh. Hal ini disebabkan bahwa factor-faktor yang mempengaruhi gizi akan berinteraksi satu sama lain sehingga berimplikasi kepada status gizi seseorang. Status gizi seimbang sangat 
penting terutama bagi pertumbuhan, perkembangan, kesehatan dan kesejahteraan manusia. kurang seimbang sehingga menyebabkan terjadinya perubahan fisik semakin cepat.

\section{Hubungan dukungan keluarga terhadap perilaku wanita menopouse}

Hasil uji statistik diperoleh nilai $\mathrm{P}=$ 0,001 dalam hal ini nilai $\alpha<0,05$ yaitu Ho ditolak dan pernyataan $\mathrm{Ha}$ diterima maka dapat disimpulkan bahwa ada hubungan dukungan keluarga dengan perilaku wanita masa menopouse. Dari hasil analisis diperoleh nilai OR 8,357, artinya dukungan keluarga baik mempunyai peluang 8,357 ( 8,4 ) kali tidak mengalami perubahan perilaku wanita masa menopouse dibanding dukungan keluarga kurang.

Hasil penelitian azka millatina 2015, yaitu uji hipotesis menunjukkan nilai koefisien korelasi $=0,658(\mathrm{p}<0,05)$, yang berarti menunjukan adanya hubungan positif yang kuat antara dukungan keluarga (sosial) perubahan perilaku pada wanita menopouse di RS harapan bunda bandung. Hasil ini menunjukan bahwa semakin tinggi perubahan perilaku pada wanita menopouse di RS harapan bunda bandung, sebaliknya semakin rendah dukungan keluarga (sosial) yang didapatkan maka semakin rendah perubahan perilaku pada wanita menopouse di RS harapan bunda bandung. Hasil ini menunjukan bahwa hipotesis yang diajukan peneliti dapat diterima.

Menurut peneliti bahwa Hal ini menggambarkan bahwa dengan dukungan keluarga yang kurang akan meningkat terjadinya perubahan perilaku pada wanita masa menopause, karena salah satu yang mempengaruhi perilaku menopouse adalah dukungan keluarga, perubahan-perubahan fisik maupun psikologi yang terjadi menyebabkan wanita membutuhkan dukungan dari oran-orang disekitarnya untuk dapat menerima perubahan yang terjadi pada dirinya yang berkaitan dengan menopouse. Perubahan dan masalah yang dialami para wanita yang menghadapi menopouse mendorong mereka untuk untuk menyelesaikan masalah yang sedang dialaminya dengan cara meminta atau mencari bantuan dari keluarga ataupun teman-temanya.

\section{KESIMPULAN}

1. Lebih dari sebagian perilaku wanita masa menopouse masih cukup besar, hal ini penyebab yang paling mempengaruhinya adalah pada faktor status gizi, yaitu sebanyak 35 responden ( 59, 3\% ) dengan nilai OR 5,778.

2. Ada hubungan antara tingkat kecemasan terhadap perilaku wanita masa menopouse dimana diperoleh nilai OR 7,600, artinya tingkat kecemasan ringan mempunyai peluang 7,6 kali tidak mengalami perubahan perilaku wanita masa menopouse dibanding tingkat kecemasan berat.

3. Ada hubungan antara status gizi terhadap perilaku wanita masa menopouse dimana Dari hasil analisis diperoleh nilai OR 5,778 , artinya status gizi baik mempunyai peluang 7,8 kali tidak mengalami perubahan perilaku wanita masa menopouse dibanding status gizi kurang.

4. Ada hubungan antara dukungan keluarga terhadap perilaku wanita masa menopouse dimana Dari hasil analisis diperoleh nilai OR 8,357 , artinya dukungan keluarga baik mempunyai peluang 8,4 kali tidak mengalami perubahan perilaku wanita masa menopouse dibanding dukunga keluarga kurang.

5. Bahwa ada faktor general lain yang mempengaruhi perilaku wanita menopouse selain yang diteliti oleh peneleti yaitu status ekonomi, pekerjaan, pendidikan,pengetahuan. 


\section{SARAN}

\section{Bagi Petugas Puskesmas Sawah Lebar Kota Bengkulu}

Hasil penelitian ini dapat dijadikan bahan masukan untuk mengupayakan peningkatan pelayanan dan penyuluhan/ konseling kepada ibu/wanita menopouse terutama tentang menopouse, serta lebih mengantisipasi secara dini komplikasi yang mungkin terjadi sehingga angka kesakitan akibat perubahan perilaku menopouse dapat menurun dengan cara memantau keadaan ibu menopouse yang mempunyai keluhan dan memeriksakan diri. Dan mengupayakan wanita menopouse untuk memeriksakan diri ke tenaga kesehatan harus didampingi keluarga sehingga untuk meningkatkan dukungan keluarga ibu menopouse tersebut.

\section{Bagi Penaliti}

Diharapkan kepada institusi pendidikan untuk lebih meningkatkan lagi materi pengetahuan serta penguasan teori tentang menopouse yang diberikan kepada mahasiswa khususnya untuk mahasiswa kebidanan, agar bisa meningkatkan pengetahuan mahasiswa sehingga mereka mahir dalam mengaplikasikan ilmunya dipelayanan kesehatan dengan baik dan benar.

\section{Bagi Institusi Pendidikan}

Diharapkan hasil penelitian ini sebagai tambahan informasi penelitian selanjutnya dapat meneliti variabel - variabel lain dan melakukan analisa lebih mendalam tentang perilaku wanita masa menopouse.

\section{DAFTAR PUSTAKA}

Almatsier, S. Gizi Seimbang Dalam Daur Kehidupan. Jakarta : PT Gramedia pustaka utama. 2011.

Aprillia, N.I. \& Puspitasari, N. Faktor yang mempengaruhi kecemasan pada wanita premonopouse. Jurnal of publica health, vol 4, No. 1, UNAIR. 2007.
Arrwenia j. Psikologi untuk kebidanan. Yogyakarta. Nuha medika. 2010.

Atikah, P. Menopouse dan sindrome premenopouse. Yogyakarta : Nuha Medika. 2010.

BKKBN. 2013. Laporan BKKBN tahun 2013. Jakarta: BKKBN.

Bethsaida j. Pendidikan psikologi untuk bidan suatu teori dan terapan. Yogyakarta: ANDI. 2013.

Data Menopouse Puskesmas Sawah Lebar Kota Bengkulu. 2016

Indrias, H, D. Hubungan Antara Perubahan Fisik Dengan Perubahan Psikologis Wanita Pada Masa Menopause Di Kelurahan Pucang Sawit Kecamatan Jebres. Skripsi. Fakultas Ilmu Kesehatan Universitas Muhammadiyah Surakarta. 2015

Millatina, A, Yanuvianti, M. Hubungan Antara Dukungan Keluarga (Sosial) Dengan Psychological Well-Being Pada Wanita Menopouse Di Rs Harapan Bunda Bandung. Skripsi. Fakultas Psikologi, Universitas Islam Bandung. 2015

Manuaba, I.B.G. Memahami KesehatanWanita. Jakarta: EGC. 2001

Nafi'ah, c. Hubungan dukungan keluarga dengan kecemasan wanita usia 40-50 tahun dalam menghadapi menopouse didusun jetak selomartani kakalasan sleman. (Skripsi) Keperawatan Tidak Dipublikasikan. Yogyakarta. Program Sekolah Tinggi Ilmu Kesehatan Aisyiyah 2009.

Notoadmodjo S. Metodologi penelitian kesehatan. Jakarta: Rineka Cipta; 2012.

Supariasa. I. Dewa Nyoman. Penilaian Status Gizi. Jakarta: EGC. 2002.

Sudibyo supartdi dan rustika. Metodelogi riset keperawatan. Jakarta : TIM. Hal 66. 2013

Susilowati. Gizi dalam daur kehidupan. Bandung. PT refika aditama. 2016.

Trisnawati, Y, suparni. Hubungan Gangguan psikologi Masa Menopause Dengan Tingkat Kecemasan Pada Ibu Menopause Di Desa Dawuhan Kecamatan Purwoasri Kabupaten Kediri. Jurnal Edu Health, Vol. 
4 No. 2. Jombang. Fakultas Ilmu Kesehatan Universitas Pesantren Tinggi Darul Ulum Jombang . 2014.

World Health Organization. Definisi Sehat WHO: WHO; 1947 [cited 201620

February]. Available from: www.who.int. 